SOCIAL RESEARCH REPORTS

ISSN: 2066-6861 (print), ISSN: 2067-5941 (electronic)

\title{
SOCIAL CAPITAL AND COMMUNITY DEVELOPMENT: CASE STUDY
}

\section{Catalin-George FEDOR}

Social Research Reports, 2019, Vol. 11, Issue 1, pp. 65-77

The online version of this article can be found at: www. researchreports.ro

\section{https://doi.org/10.33788/srr11.1.5}

Published by:

Expert Projects Publishing House

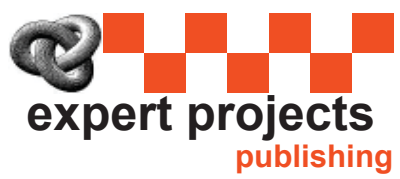

Covered by Index Copernicus International www.indexcopernicus.com

Directory of Open Access Journals www.doaj.org On behalf of:

Center for Program and Social Development

Aditional services and information about Social Research Reports can be found at: www.researchreports.ro 


\title{
SOCIAL CAPITAL AND COMMUNITY DEVELOPMENT: CASE STUDY
}

\author{
Catalin-George FEDOR ${ }^{1}$
}

\section{Abstract}

This paper presents the results of a research on the role played by social capital in the development of a community. The aim is to reveal the virtues of the social capital concept and to analyse its practical value on the ground. The focus is on how a community reacts to the development proposals received from different social agents. The results show the different ways in which community members respond to the proposed initiatives according to their age and training. The conclusions highlight the fact that in the collective consciousness, there are multiple representations of the common future of a community.

Keywords: social capital, community development, social relations.

\section{Introduction}

We generally perceive local community as a more or less homogenous group made up of people who assert a certain form of identity given by the consciousness of a past or a common origin. This identity (often assimilated to the local specificity) is equally built by members of that community. This fact that we can call consciousness is grounded on some relatively objective criteria, such as the place, institutions or cultural traits containing aspirations and joint projects. It results that community membership seen as consciousness can be defined by the meaning given by the individual to the criteria listed above (Fedor, 2014). Our study focuses on the social capital of members of a community. From our point of view, it refers to the relations between people, the so-called social networks, rules of reciprocity, and generalized trust among people. Social capital is very close to civic virtue, a virtue that calls for mutual social relations. Regardless of the different aspects of its definition, a common tendency is preserved by the idea of resource available to the individual or to a social formation. In this respect, we studied the availability and the involvement degree of community members in the implementation of initiatives of community interest proposed by local authorities, central authorities, international institutions, as well as the reliable people from the community. In this regard, we will point out that affiliation to a specific local community (in our case the one from Buzau county) is a dynamic process that

${ }^{1}$ Romanian Academy, Iaşi, ROMANIA. E-mail: cgfedor@yahoo.com 
presents both aspects present in collective memory and aspirations for the future, is a process in which periodical reconfigurations are produced and in which the role of inter-relationship (with the trusted person, with authority, with the other, in general) is decisive and visible.

\section{Theoretical aspects}

From a theoretical perspective, Bourdieu (1986), Coleman $(1988,1990)$ and Putnam (1993) were the ones who developed the concept of social capital. Bourdieu discussed the effects of social capital, particularly on an individual level. Coleman explicitly developed the theory by placing it at community level. Putnam theorized social development in terms of social capital. The concept is versatile and prolific, being criticized precisely for this reason. It was used autonomously, but also in correlation with other forms of capital such as economic, political, cultural and symbolic. Further on, we shall present its main meanings, fields of application (from a theoretical perspective), as well as results from various field investigations. We mention that the specialized literature devoted to this subject is extremely extensive, and our approach is a synthetic presentation to familiarize the reader with the subject.

Social capital is an eminently sociological concept used in various branches of sociology and, by extension, in all social sciences. It generally refers to relations between people, so-called social networks, rules of reciprocity and generalized trust among people. The major critique of the concept lies in the dual quality of social capital as a means of analysis and as a political objective. A review of literature in the context of developed countries indicates that this concept is rarely as easy to apply at community level as it is presented in the literature on community development. The ideas on social and community capital were carefully studied lately, Colclough and Sitaraman (2005), but they are affected by a multitude of concepts, definitions and operations. This confusion is problematic for researchers as well as decision-makers trying to use these concepts. Although many efforts have been made to clarify "social capital" and "community", the two concepts are most frequently merged into current practice, which requires a delimitation of them. Both advocates and critics of the concept preferred to address the "nature" of social capital, as specialised literature on social capital continued to flourish over recent decades. Chamlee-Wright (2008) believes that social capital can be understood as being of a structural nature, consisting of heterogeneous and often complementary elements. The theoretical debate leads us to relate the literature about the network analysis (emphasizing the individualist accumulation of social capital) and wider social capital issues incorporated into the community norms. Moreover, the development of social capital can or must be part of a deliberate (community, regional or national) development strategy.

On a different note, the tendency to consider the concept of social capital as fecund used only in an autonomous manner, without taking into account the economic capital, was criticized. DeFilippis (2001) argues that the contemporary interest in social capital from theoreticians, funders and community development practitioners is wrong and must be thoroughly reviewed. This form of capital is a 
fundamentally erroneous concept because it is separated from the economic capital. Therefore, according to the author, the community development practice based on this understanding of social capital is and will be erroneous. As a consequence, the practice of community development would be better served by returning to the way the concept was used by Bourdieu. Crowe (2006) considers that social capital is a key concept in rural sociology and community study. In this respect, researchers increasingly correlate studies of social capital with the environment, examining the factors that facilitate economic development. As a result, the social infrastructure of a community (measured by the existence of civic organizations active, local businesses that support local community projects, fundraising capacity at community level and extra-local links with nearby communities, with the state and national agencies) influence positive self-development process.

Starting from some examples of research conducted in rural area, Swain (2003) illustrated how this concept can be used both in analysing social relationships and in suggesting policy priorities. The author's conclusion is that, irrespective of the way in which it is interpreted, social capital is by no means the "missing link" in the development economy, yet social capital, as it derives from Bourdieu, may be a useful concept in everyday social analysis. Xia (2014) proposed to examine the stock of social capital and explore its various impacts on the performance of economic development. Social capital, as manifested through general confidence and inclusive social networks, has positively affected the development performance of the studied communities.

The current interest in the concept of social capital in the field of national development results from the limitations of an exclusively economic approach in achieving fundamental development objectives consisting of sustained growth, equity and democracy, according to Portes and Landolt (2000). Starting from a review of the origins and definitions of the social capital concept as developed in recent literature, the authors present the limitations of this concept when interpreted as a causal force capable of transforming communities and nations. However, although the different types of capital have been identified and studied as engines of economic development in particular contexts, social capital can also play an important role in the economic development of a country, according to Doh and Mcneely (2012), who intended to examine social capital in relation to its impact on economic development at country level and highlighting its implications for policy guidance at national level.

Campbell, Hughes, Hewstone and Cairns (2010) define social capital as a mechanism for building a sustainable society. They believe that in recent years, democratic societies have followed the trend of developing and exploiting social capital. This can be noticed in the development of public policy programs that highlighted the importance of developing relationships, both within and between communities, as well as between communities and state-level organizations. Social capital is seen as a political concept that has the value of interpreting community dynamics, developing strategies to strengthen relationships and community development, and ultimately building a more sustainable society.

Social association includes rules, norms and informal values that facilitate coordinated action for members of society and allow for cooperative associations that would otherwise be impossible. Hence the importance of social capital in 
the process of economic development (Fedderke, De Kadt, Luiz, 1999). Kwon, Heflin and Ruef (2013) notes that individuals in communities with a high level of social trust are more likely to be independent than individuals in communities with lower levels of social trust. In addition, membership in organizations connected to a larger community is associated with higher levels of self-employment, but membership of isolated organizations not linked to the larger community is associated with lower levels of self-employment.

Social capital analysis to determine its effect on economic growth is a complex field of investigation. Neira and Vazquez (2009) examine the relationships that exist between human and social capital and economic growth, starting from assessing how the two types of capital (human and social) interact, the whey in which they should be measured and the best way of quantifying their importance in the models applied to economic growth.

The social capital concept is increasingly used in the field of community development and social economy. The way in which social capital can be used in the context of community development can also have a number of political implications (Kay, 2006). He presents the results of a research project that analyses the contribution of social capital to social economy within local economic development. Over the past few years, interest in the social economy has intensified both in theory and in public policy initiatives. At the same time, the concerns for understanding the contribution of social economy and social capital to local economic development have also been emphasized, Negut (2013) shows. By their flexible nature and orientation predominantly towards social goals rather than profit maximization, social economy organizations can adapt more easily to development needs, taking into account the values of the actors involved in the process. The author explores the notion of social capital and describes the way in which it is generated and used in social economy. By reviewing the main risks associated with development policies centred on social capital, the author does not overestimate its role. The stock of social capital has proved to be an important factor in determining the potential for the establishment of a social enterprise or community development but it is not the only factor to be taken into account and has no capacity to substitute the lack of other resources. In addition, the relationship between bonding and bridging social capital should not be neglected, the excessive inclination towards one of them having considerable effects on the implementation of local development projects and the development of social enterprises. Bonding social capital characterizes small, closed communities, based on relations within the group of belonging and mistrust in others, whether individuals or institutions. On the other hand, communities with high levels of bridging capital are characterized by relationships with groups other than primary ones and high levels of trust in them and in institutions, as well as participation in the work of associations. On the other hand, the focus on a certain type of social capital in relation to social economy may vary depending on the stage of development of social enterprise. The private and voluntary initiative must be supported by the community. In relation to this, it is recommended to build an appropriate basis in order to support the change. This can be structured at various levels and refers to the methods that the social economy provider can resort to in order to offer support for the establishment of social enterprises by the people involved, especially the 
promoters, who can expand the project and, last but not least, by the community that lacks resources to run the projects and keep them running (Fedor, 2016a). The main benefit for the community is the expected change in behaviour, attitude and identity (Fedor, 2016b).

More recently, McShane (2016) considers it necessary to review the literature that can highlight the challenges of social capital operationalization as a development tool and the limits of research that measure the perception of the community about the role of social capital in the development of a region. The findings suggest to stakeholders that the way in which social capital is perceived is important to regional development.

Community-based development is based on the principle of development aid through community participation, which is expected to promote pro-social behaviour. Thus, as Nguyen and Rieger (2017) show, programs can be developed that focus on the importance of social capital measured by field-based economic experiments.

The concept of social capital has gained a great deal of importance in the past and its relation to the identification of factors that influence the level of education of individuals. Thus, explanations have emerged regarding the different levels of participation in formal and informal education of adults and the conditions required for building and developing institutions and practices that contribute to lifelong learning. In this respect, the increase in social capital seems to be directly related to community development education, meaning that community development is generally defined as a social learning process that empowers individuals and their involvement as citizens in collective activities aimed at socio-economic development. In this context, McClenaghan (2000) questions the validity and effectiveness of social capital as an analytical concept in the field of adult education research. Another viewpoint was asserted by Kilpatrick, Field and Falk (2003). They consider that, since the social capital concept is not able to combat the complex social divisions that characterize contemporary society, a relation can be identified between social capital and community development, especially through adult education for the development of the community, as a central area in which the scientific and political interests overlap. Gagacka (2016) believes that professional counselling can lead to the increase in human and social capital. This counselling responds to the states of uncertainties and social risks determined by the dynamic changes of contemporary life. The request for counselling is not only for people who want to develop their own career quickly and efficiently but also for those who fail to function in the realities of current labour markets or meet their professional requirements and family roles. Areekul, Ratana-Ubol and Kimpee (2015) believe that this capital can be strengthened through a lifelong learning system. They have determined the components of social capital that consist of culture and knowledge at human and institutional level, community funds and natural resources. The social capital of a community is based on trust in all its stages of consolidation. This involves the confident participation of community members in studying community issues, engagement in decision-making, implementation, sharing benefits, and taking part in assessing these stages.

Social capital can help strengthen social infrastructure at community level, according to Aldrich and Meyer (2015). In this respect, referring to the resilience 
of communities, the authors highlight the critical role of social capital and networks in the survival and recovery of communities following tough times. Social capital can be viewed, as noted before, in terms of social networks as well. Ennis and West (2013) propose integrating social networking into community development practice as a useful way to communicate the relations between micro- and macroeconomic issues in communities and to explore the impact of community development work. The authors demonstrate that social network analysis is a useful tool for facilitating community development and measuring the effectiveness of community development projects.

\section{Research methods}

We chose survey research as a statistical method of knowing a population based on the data recorded on a representative group (sample) extracted from that population. In our approach we preferred a random survey by unrepeatable selection (Fowler, 2002). We worked on the young population represented by high school students, starting with the age of 15 , on the adult (19-29 years), mature (30-64 years) and elderly (65 years and more) population. In order to create a representative sample, we resorted to data kept by the National Institute of Statistics (NIS). According to data provided by NIS, according to the latest census (carried out in 2011), Buzau has a stable population of 115,494 inhabitants, of which $84.4 \%$ are over 15 years old (http: // statistici.insse.ro). The 383 individuals included in our sample were divided into two target groups, namely adults (including mature and elderly individuals) and high school students. Thus, we canvassed 311 adult subjects of both sexes, of various ages and with different education levels. The other canvassed group included 72 high school students.

We used an adapted form of the social distance scale, starting from the Bogardus model (1925), which became by extension, the most used method for emphasizing acceptance or rejection of initiatives / institutions / social groups / etc.

\section{Results and discussion}

\section{Results concerning all the surveyed population}

Sample distribution shows that $40.6 \%$ of the respondents would get sufficiently involved in the local government's initiatives concerning Buzau Town. An almost similar share of respondents claimed that they would get very involved in the various initiatives concerning Buzau Town. Almost half of the people participating in the survey stated that they would get sufficiently involved in initiatives proposed by the central government (47.4\%). If international institutions developed initiatives concerning Buzau Town, most respondents would get involved in them to a very great extent $(44.8 \%)$. More than half of the respondents said that if people they trust developed initiatives for Buzau Town, they would get very involved. 
Table 1. Degree of involvement in various initiatives of the whole population surveyed

\begin{tabular}{|l|l|l|l|l|}
\hline $\begin{array}{l}\text { Involvement in initiatives } \\
\text { proposed by... }\end{array}$ & \multicolumn{1}{|c|}{$\begin{array}{c}\text { Very much } \\
(\%)\end{array}$} & $\begin{array}{c}\text { Sufficiently } \\
(\%)\end{array}$ & $\begin{array}{c}\text { A little } \\
(\%)\end{array}$ & $\begin{array}{c}\text { Not at all } \\
(\%)\end{array}$ \\
\hline local government & 35.6 & 40.6 & 15.3 & 8.5 \\
\hline central government & 15.3 & 47.4 & 28.8 & 8.5 \\
\hline international institutions & 44.8 & 19.0 & 27.6 & 8.6 \\
\hline people I trust & 53.3 & 25.0 & 11.7 & 10.0 \\
\hline
\end{tabular}

*Data source: personal processing

\section{Results concerning the adult, mature and elderly population}

More than half of the respondents claimed that if local government authorities had initiatives concerning Buzau Town, they would get very involved. $63 \%$ of the respondents to our questionnaire would get sufficiently involved in the central government's initiatives. According to the table data, more than half of the respondents would like to get very involved in various initiatives initiated by international institutions. More than half of the respondents want to get very involved in the initiatives concerning Buzau Town suggested by people they trust $(59.3 \%)$.

Table 2. Degree of involvement in various initiatives of the adult, mature and elderly population

\begin{tabular}{|l|l|l|l|l|}
\hline $\begin{array}{l}\text { Involvement in initiatives } \\
\text { proposed by... }\end{array}$ & $\begin{array}{c}\text { Very much } \\
(\%)\end{array}$ & $\begin{array}{c}\text { Sufficiently } \\
(\%)\end{array}$ & $\begin{array}{c}\text { A little } \\
(\%)\end{array}$ & $\begin{array}{c}\text { Not at all } \\
(\%)\end{array}$ \\
\hline local government & 51.9 & 37.0 & 3.7 & 7.4 \\
\hline central government & 63.0 & 22.2 & 11.1 & 3.7 \\
\hline international institutions & 51.9 & 22.2 & 22.2 & 3.7 \\
\hline people I trust & 59.3 & 18.5 & 14.8 & 7.4 \\
\hline
\end{tabular}

\section{* Data source: personal processing}

Let us get a little more insight into the respondents' age. 33.3\% of the respondents aged between 30 and 64 years confirmed that they would get sufficiently involved in various initiatives of local government authorities. More than half of the interviewed individuals aged between 30 and 64 years stated that they would get sufficiently involved in various initiatives initiated by the central government $(55.6 \%) .44 .4 \%$ of the respondents aged between 30 and 64 years would like to get very involved in initiatives coming from international institutions. We found that $3.7 \%$ of the elderly respondents would like to get very involved in initiatives initiated by people they trust concerning Buzau Town. 
Table 3. Degree of involvement in various initiatives of the adult, mature and elderly population, on age groups

\begin{tabular}{|c|c|c|c|c|}
\hline $\begin{array}{l}\text { Initiatives proposed } \\
\text { by... }\end{array}$ & \begin{tabular}{|l} 
Degree of \\
involvement
\end{tabular} & $19-29$ years & $30-64$ years & $65-X$ years \\
\hline \multirow{4}{*}{ local government } & Very much & $11.1 \%$ & $37.0 \%$ & $3.7 \%$ \\
\hline & Sufficiently & $3.7 \%$ & $33.3 \%$ & \begin{tabular}{|l|}
-- \\
-
\end{tabular} \\
\hline & A little & -- & $3.7 \%$ & -- \\
\hline & Not at all & -- & $7.4 \%$ & - \\
\hline \multirow{4}{*}{ central government } & Very much & $7.4 \%$ & $14.8 \%$ & -- \\
\hline & Sufficiently & $3.7 \%$ & $55.6 \%$ & $3.7 \%$ \\
\hline & A little & $3.7 \%$ & $7.4 \%$ & -- \\
\hline & Not at all & -- & $3.7 \%$ & -- \\
\hline \multirow{4}{*}{$\begin{array}{l}\text { international } \\
\text { institutions }\end{array}$} & Very much & $7.4 \%$ & $44.4 \%$ & -- \\
\hline & Sufficiently & $3.7 \%$ & $18.5 \%$ & -- \\
\hline & A little & $3.7 \%$ & $14.8 \%$ & $3.7 \%$ \\
\hline & Not at all & -- & $3.7 \%$ & -- \\
\hline \multirow{4}{*}{ people I trust } & Very much & \begin{tabular}{|l}
- \\
-
\end{tabular} & $55.6 \%$ & $3.7 \%$ \\
\hline & Sufficiently & $3.7 \%$ & $11.1 \%$ & -- \\
\hline & A little & $7.4 \%$ & $11.1 \%$ & -- \\
\hline & Not at all & $3.7 \%$ & $3.7 \%$ & -- \\
\hline
\end{tabular}

* Data source: personal processing

Here is more in-depth information about the answers depending on the respondents' level of education. $29.6 \%$ of all the respondents who are higher education graduates would get sufficiently involved in any local government initiatives. Almost half of the subjects are higher education graduates and wish to get sufficiently involved in initiatives suggested by central government. $25.9 \%$ of the respondents who are university graduates agreed to get very involved in the initiatives proposed by international institutions for Buzau Town. The highest percentage was recorded among university graduates who wish very to get involved in initiatives proposed by people they trust $(40.7 \%)$.

Table 4. Degree of involvement in various initiatives of the adult, mature and elderly population, depending on their education level

\begin{tabular}{|l|l|l|l|l|l|}
\hline Involvement in initiatives proposed by local government authorities \\
\hline Degree of involvement & 10 grades & High school & College & $\begin{array}{l}\text { Higher } \\
\text { education }\end{array}$ & $\begin{array}{l}\text { Graduate } \\
\text { education }\end{array}$ \\
\hline Very much & $7.4 \%$ & $11.1 \%$ & $7.4 \%$ & $14.8 \%$ & $11.1 \%$ \\
\hline Sufficiently & -- & $3.7 \%$ & $3.7 \%$ & $29.6 \%$ & -- \\
\hline A little & -- & -- & -- & $3.7 \%$ & -- \\
\hline Not at all & -- & -- & $3.7 \%$ & -- & $3.7 \%$ \\
\hline
\end{tabular}




\begin{tabular}{|c|c|c|c|c|c|}
\hline Degree of involvement & 10 grades & High school & College & $\begin{array}{l}\text { Higher } \\
\text { education }\end{array}$ & $\begin{array}{l}\text { Graduate } \\
\text { education }\end{array}$ \\
\hline Very much & -- & $11.1 \%$ & $7.4 \%$ & -- & $3.7 \%$ \\
\hline Sufficiently & \begin{tabular}{|l|}
-- \\
\end{tabular} & $3.7 \%$ & $3.7 \%$ & $48.1 \%$ & $7.4 \%$ \\
\hline A little & $7.4 \%$ & -- & $3.7 \%$ & -- & -- \\
\hline Not at all & -- & -- & -- & -- & $3.7 \%$ \\
\hline \multicolumn{6}{|c|}{ Involvement in initiatives proposed by international institutions } \\
\hline Degree of involvement & 10 grades & High school & College & $\begin{array}{l}\text { Higher } \\
\text { education }\end{array}$ & $\begin{array}{l}\text { Graduate } \\
\text { education }\end{array}$ \\
\hline Very much & -- & $11.1 \%$ & $7.4 \%$ & $25.9 \%$ & $7.4 \%$ \\
\hline Sufficiently & -- & $3.7 \%$ & $7.4 \%$ & $7.4 \%$ & $3.7 \%$ \\
\hline A little & $7.4 \%$ & -- & -- & $14.8 \%$ & -- \\
\hline Not at all & -- & -- & -- & -- & -- \\
\hline \multicolumn{6}{|c|}{ Involvement in initiatives proposed by people I trust } \\
\hline Degree of involvement & 10 grades & High school & College & $\begin{array}{l}\text { Higher } \\
\text { education }\end{array}$ & $\begin{array}{l}\text { Graduate } \\
\text { education }\end{array}$ \\
\hline Very much & -- & -- & $7.4 \%$ & $40.7 \%$ & $11.1 \%$ \\
\hline Sufficiently & -- & $3.7 \%$ & $3.7 \%$ & $3.7 \%$ & $3.7 \%$ \\
\hline A little & -- & $11.1 \%$ & $3.7 \%$ & $3.7 \%$ & -- \\
\hline Not at all & $7.4 \%$ & -- & -- & -- & -- \\
\hline
\end{tabular}

* Data source: personal processing

\section{Results concerning the young population}

More than $40 \%$ of respondents would get sufficiently involved in initiatives proposed by local government authorities. We noticed that $47 \%$ of the students participating in the survey said that they would have little involvement in the initiatives proposed by the central government authorities. If some international institutions proposed various initiatives for Buzau, most of the respondents would get involved to a very large extent $(44.1 \%)$. Nearly half of the surveyed students $(49.9 \%)$ said that if people they trust suggested initiatives to support Buzau, they would get very involved.

Table 5. Degree of involvement in various initiatives of the young population

\begin{tabular}{|l|l|l|l|l|}
\hline $\begin{array}{l}\text { Involvement in initiatives } \\
\text { proposed by... }\end{array}$ & $\begin{array}{c}\text { Very much } \\
(\%)\end{array}$ & $\begin{array}{l}\text { Sufficiently } \\
(\%)\end{array}$ & $\begin{array}{c}\text { A little } \\
(\%)\end{array}$ & $\begin{array}{l}\text { Not at all } \\
(\%)\end{array}$ \\
\hline local government & 21.9 & 43.7 & 25.0 & 9.4 \\
\hline central government & 8.8 & 32.4 & 47.0 & 11.8 \\
\hline international institutions & 44.1 & 29.4 & 14.7 & 11.8 \\
\hline people I trust & 49.9 & 32.4 & 11.8 & 5.9 \\
\hline
\end{tabular}

\footnotetext{
* Data source: personal processing
} 


\section{Results in the mirror}

We want to highlight a very interesting set of results, referring to the social capital of the Buzau community. Please note that we use the idea of social capital in the sense of willingness to be involved in joint community development projects. The first results are those for the entire population of Buzau. Thus, regarding the population involvement in the initiatives proposed by the local government authorities, according sample distribution, $40.6 \%$ of the respondents would get sufficiently involved and almost the same percentage of respondents (namely $35.6 \%$ ) said that they would get very involved in these initiatives. Almost half of the respondents said that they would get sufficiently involved in the initiatives proposed by the central authorities $(47.4 \%)$, whereas $15.3 \%$ would get very involved. If international institutions suggested initiatives for Buzau Town, most respondents would get involved to a very large extent $(44.8 \%)$, followed by those who would get sufficiently involved (19.0\%). Also, 53.3\% of respondents claimed that, if people that they trust proposed initiatives for Buzau, they would also get very involved, whereas a quarter of the population surveyed (25.0\%), would get sufficiently involved.

Here is also a mirror presentation of the results. Over half of the adult, mature and elderly respondents $(51.9 \%)$ stated that if local authorities were to propose initiatives for Buzau, they would get very involved, and $37.0 \%$ would get pretty involved. The share of people who would like to get sufficiently involved in central government initiatives is $63.0 \%$, followed by those who would get very involved $(22.2 \%)$. As one may also notice, over half of the respondents $(51.9 \%)$ would like to get very involved in various initiatives that international institutions would launch, and $22.2 \%$ would get sufficiently involved such initiatives. More than half of respondents want to get very involved in the initiatives concerning Buzau Town proposed by people they trust $(59.3 \%)$. Those who would be involved enough are $18.5 \%$ of them would get sufficiently involved. For all categories of proposed initiatives, the highest share of respondents is the active population segment (30 to 64 years of age) with a higher level of training.

As far as the young population is concerned, $43.7 \%$ of respondents would get sufficiently involved, and $21.9 \%$ of them very involved in initiatives proposed by local authorities. We did notice the same level of enthusiasm for central government initiatives, as $47.0 \%$ of the surveyed students said that they would have little involvement in the initiatives proposed by the central authorities. On the other hand, if some international institutions proposed different initiatives for Buzau Town, most respondents would get involved to a very large extent (44.1\%). Nearly half of the students participating in the survey (49.9\%) said that if people they trust suggested initiatives to support Buzau Town, they would get very involved and $32.4 \%$ would get sufficiently involved. 
Table 6. Comparison of results

\begin{tabular}{|l|l|l|l|l|l|}
\hline Respondents & $\begin{array}{c}\text { Degree of } \\
\text { trust }\end{array}$ & $\begin{array}{c}\text { Local } \\
\text { authorities } \\
(\%)\end{array}$ & $\begin{array}{c}\text { Central } \\
\text { authorities } \\
(\%)\end{array}$ & $\begin{array}{c}\text { International } \\
\text { institutions } \\
(\%)\end{array}$ & $\begin{array}{c}\text { People they } \\
\text { trust } \\
(\%)\end{array}$ \\
\hline \multirow{2}{*}{$\begin{array}{l}\text { Total } \\
\text { population }\end{array}$} & Very much & 35.6 & 15.3 & 44.8 & 53.3 \\
\cline { 2 - 7 } & Sufficiently & 40.6 & 47.4 & 19.0 & 25.0 \\
\cline { 2 - 7 } $\begin{array}{l}\text { Adults, } \\
\text { mature, } \\
\text { elderly }\end{array}$ & Total & 76.2 & 62.7 & 63.8 & 78.3 \\
\hline \multirow{3}{*}{ Young } & Sufficiently & 51.9 & 63.0 & 51.9 & 59.3 \\
\cline { 2 - 7 } & Total & 88.9 & 22.2 & 22.2 & 18.5 \\
\cline { 2 - 7 } & Very much & 21.9 & 85.2 & 74.1 & 77.8 \\
\cline { 2 - 7 } & Sufficiently & 43.7 & 32.4 & 44.1 & 39.9 \\
\cline { 2 - 7 } & Total & 65.6 & 41.2 & 73.5 & 82.3 \\
\hline
\end{tabular}

* Data source: personal processing

\section{Conclusions}

Thus, for the total population, the best scores (i.e. "very much" and "sufficiently/pretty much") were found for the initiatives proposed by local authorities and the people they trust, followed by those proposed by international bodies and by central authorities. In the adult, mature and elderly population, the best scores are by far those for local government initiatives (about $90 \%$, the best score in all rankings), followed by initiatives of community leaders, and then by those proposed by central authorities and international ones. The results are different for the young population segment, where the best score was found for the initiatives of private individuals, trusted acquaintances, followed by international institutions, local authorities and, last, central authorities.

Thus, for the whole population surveyed in our research, as well as on age categories, the most trusted are local government authorities and people they know, who are leaders in their community.

\section{References}

Aldrich, D. P., Meyer, M. A. (2015). Social Capital and Community Resilience. American Behavioral Scientist, 59(2), 254-269.

Areekul, C., Ratana-Ubol, A., Kimpee, P. (2015). Model Development for Strengthening Social Capital for Being a Sustainable Lifelong Learning Society. Procedia - Social and Behavioral Sciences, 191, 1613-1617.

Bogardus, E. (1925). Social Distance Scale. Sociology and Social Research, 1. Bourdieu, P. (1986). The Forms of Capital. In J. G. Richardson (Ed.), Handbook of Theory and Research for the Sociology of Education (241-258). New 
York: Greenwood Press.

Campbell, A., Hughes, J., Hewstone, M., Cairns, E. (2010). Social capital as a mechanism for building a sustainable society in Northern Ireland. Community Development Journal, 45(1), 22-38.

Chamlee-Wright, E. (2008). The Structure of Social Capital: An Austrian Perspective on its Nature and Development. Review of Political Economy, 20(1), 41-58.

Colclough, G., Sitaraman, B. (2005). Community and Social Capital: What Is the Difference? Sociological Inquiry, 75(4), 474-496.

Coleman, J. (1988). Social Capital in the Creation of Human Capital. American Journal of Sociology, 94, 94-120.

Coleman, J. (1990). Foundations of Social Theory, Cambridge: Harvard University Press.

Crowe, J. A. (2006). Community Economic Development Strategies in Rural Washington: Toward a Synthesis of Natural and Social Capital. Rural Sociology, 71(4), 573-596.

DeFilippis, J. (2001). The myth of social capital in community development. Housing Policy Debate, 12(4), 781-806.

Doh, S., Mcneely, C. L. (2012). A multi-dimensional perspective on social capital and economic development: an exploratory analysis. The Annals of Regional Science, 49, 821-843.

Ennis, G., West, D. (2013). Using social network analysis in community development practice and research: a case study. Community Development Journal, 48(1), 40-57.

Fedderke, J., De Kadt, R., Luiz, J. (1999). Economic growth and social capital: A critical reflection. Theory and Society, 28(5), 709-745.

Fedor, C. (2014). Towards a Postmodern Approach of Ethnic Community. Postmodern Openings, 5(2), 71-80.

Fedor, C. (2016a). Social Economics and Community Identity. Journal of Social Economy, 6(1), 35-52.

Fedor, C. (2016b). Local Specificity and Social Economy. Journal of Social Economy, 6(2), 16-28.

Fowler, F. Jr. (2002). Survey Research Methods (3rd ed.). Sage Publications.

Gagacka, M. (2016). The role of guidance in the increasing of human and social capital. Roczniki Teologiczne, 63(1), 21-38.

Kay, A. (2006). Social capital, The social economy and community development, Community Development Journal, 41(2), 160-173.

Kilpatrick, S., Field, J., Falk, I. (2003). Social Capital: An analytical tool for exploring lifelong learning and community development. British Educational Research Journal, 29(3), 417-433.

Kwon, S.W., Heflin, C., Ruef, M. (2013). Community Social Capital and Entrepreneurship. American Sociological Review, 78(6), 980-1008. 
McClenaghan, P. (2000). Social Capital: Exploring the theoretical foundations of community development education. British Educational Research Journal, 26(5), 565-582.

McShane, C.J. et al. (2016). Connections: the contribution of social capital to regional development. Rural Society, 25(2), 154-169.

Negut, A. (2013). Economie sociala, capital social şi dezvoltare locala. Calitatea vietii, 24(2), 195-212.

Neira, I., Vazquez, E. (2009). An Empirical Analysis of Social Capital and Economic Growth in Europe (1980-2000). Social Indicators Research, 92(1), 111-129.

Nguyen, T.C., Rieger, M. (2017). Community - Driven Development and Social Capital: Evidence from Morocco. World Development, 91, 28-52.

Portes, A., Landolt, P. (2000). Social Capital: Promise and Pitfalls of its Role in Development. Journal of Latin American Studies, 32(2), 529-547.

Putnam, R., Leonardi, R., Nanetti, R. (1993). Making Democracy Work: Civic Traditions in Modern Italy. Princeton: Princeton University Press.

Swain, N. (2003). Social Capital and its Uses. European Journal of Sociology, 44(2), 185-212.

Xia, M. (2014). Social Capital and Socioeconomic Development in Rural China. Fudan Journal of the Humanities and Social Sciences, 7(4), 563-581. 